\title{
Production and Marketing Constraints for Cumin Seed in Barmer District
}

\author{
Pradeep Pagaria $^{1}$ and Sonali Sharma ${ }^{2}$ \\ ${ }^{1}$ Krishi Vigyan Kendra, Gudamalani - Barmer (Rajasthan), India \\ ${ }^{2}$ Krishi Vigyan Kendra-Barmer (Rajasthan), India \\ *Corresponding author
}

\section{Keywords}

Cumin, Marketing,

Constraints,

Ranking, Mandis

Article Info

Accepted:

15 February 2019

Available Online:

10 March 2019

\section{A B S T R A C T}

Cumin (Cuminum cyminum) is an important low volume high value seed spices grown in India. India is the largest producer and consumer of cumin seed in the world while Gujarat is leading in production and Rajasthan in acreage (Table 1). Cumin is grown on 104828 ha area with an annual production of 28410 tonnes in Barmer district with an average productivity of $348 \mathrm{~kg} / \mathrm{ha}$. About $90 \%$ of the total production is marketed in Krishi Upaj Mandis of adjoining state i.e. Unjha, Deesa, Mehsana etc of Gujarat instead of Rajasthan. The yield of cumin crop is adversely affected by incidence of wilt and blight diseases and attack of aphid while economic returns were drastically affected by marketing problems. Besides this, farmers practicing traditional method of cultivation since a long time resulted in decrease in productivity. In view of this a study was conducted in three village of Gudamalani tehsil of Barmer district in Rajasthan. A set of personnel interview, questionnaire and farm inventory were used to collect basic information and production and marketing constraints from these selected farmers. The variables were scored according to scale already developed and in-use in the extension research studies. The data were analyzed and interpreted in terms of frequencies, percentage and score value. The farmers ranked different constraints like the non declaration of minimum support prizes, unavailability of storage structures, unavailability of loaning facilities, lack of laboratory for testing the seed for quality parameters, lack of processing units etc. are as major constraints and they were ranked $1,2, \ldots$ and so on respectively.

\section{Introduction}

Cumin is an important seed spices in India. Cumin seeds have an aromatic fragrance due to an alcohol 'cuminol'. The seeds are largely used as condiments in the form of an essential ingredient in all mixed spices and in curry powder for flavouring, vegetables, pickles, soups etc. It also has medicinal properties and is used in treatment of carminative, stomachic, astringent and in diarrhea. Cumin is largely exported in form of seed and some quantities in the form of seed oil, cumin powder and oleoresin India is biggest exporter of cumin seed, powder and oils to Japan, Korea, USA etc. As the government has more awake on public health and targeted to produce chemical free (organic) seeds and other products. The individual country has decided permissible limits of residue before accepting it for import. 
The exporters must consider the permissible limits of chemical in export material to avoid rejection of material to get more foreign exchange. Cumin is the major Rabi crop of western Rajasthan (Jodhpur, Barmer, Jalore, Jaiselmer, Nagore, Pali etc.) and contributes around $95 \%$ of total acreage and $91 \%$ in production (Table 1). More than $50 \%$ of the total production is marketed in Krishi Upaj Mandis of Gujarat i.e. Unjha, Deesa, Mehsana etc instead in local Mandies.

\section{Materials and Methods}

The productivity in state could be enhanced through adoption of improved technologies particularly by adequate supply of improved seed (wilt resistant variety), availability of non persistent chemicals for soil and seed treatment, IPM and ICM practices have been assessed (Table 2). In view of this the study was conducted in three village of Gudamalani tehsil of Barmer district in Rajasthan during implementation of project on IPM with ITC Limited. These were selected after comprehensive laboratory analysis of soils and seed of previous crop for residue of plant protection chemicals. These three villages were Dudasar, Mittiberi and Laxmanpura with sample size of 26, 25 and 17, respectively (A total 68 farmers constituting 120 ha). The farmers were selected after developed personnel interview, questionnaire and farm inventory to collect basic information regarding PoP's (Choudhary and Pagaria 2012). The major source of irrigation was sprinkler method because soils in these areas are sandy to sandy loam with high infiltration rates. Besides this, the ground water table is very deep water along with brackish in nature. To understand the knowledge of farmers about latest technologies, adoption level, consultancy pattern and other possible reasons of non adoption were considered as dependent variable. The variables were scored according to scale developed and in-use in the extension research studies. The data were analyzed and interpreted in terms of frequencies, percentage and score value.

\section{Results and Discussion}

\section{Production Constraints in adoption of improved technology}

Cumin is almost grown on assured irrigated condition where input supply is only limited by either availability of inputs or economic conditions of the growers. The soils are sandy to sandy loam with undulating topography forced the farmers to follow broadcasting method of sowing followed by mixing with cultivator resulted into uneven and poor germination and un-uniform crop stand (Veerasamy et al., 2003). Similarly it restricts the use of modern equipments for inter cultivation. These practices increased the cost of cultivation as they need higher seed rate (15 $\mathrm{kg}$ of seed instead of $5 \mathrm{~kg}$ ) and more number of costly labours for field operations. The results of study related to production constraints, the grower's ranked the lack of suitable seed drill for cumin sowing (shallow) as top and prime constraint (Table 3). The timely availability of improved seed variety resistant to wilt was the major constraints for adoption of improved practices. Similarly, the government polices like lack of subsidies on inputs and plant protection measures, poverty etc. also hinders the adoption of improved packages. The increased rate of wages for labours and their engagement in MNREGA affected timeliness of farm operations.

\section{Marketing Constraints in adoption of improved technology}

The cumin is cultivated in India on $1 \mathrm{~m}$ ha (Approx.) and there is no declaration of MSP. Once the government declares it, a gradual increase in sell prices noticed yearly. But the cumin prices are stable and are around Rs. 
100-120/- kg during last decade in comparison to the increase in prices by two to three folds of other crops (Table 4).

The results of present study reveal that the non declaration of MSP was top most constraint as reflected by sizable farmers. The produce was sold in market just after harvesting to local vendors to pay the wages, fulfill daily requirement and loans by cooperatives due to economic conditions of the farmers. In this regards, the lack of loan against property
(Cumin) is not provided by buyer in Rajasthan as compared to Gujarat (II constraint). The quality of cumin deteriorate day by day and there is a shortage of storage facility for large scale along with lack of processing unit for grading (was also hinder the production of cumin. The facilities for determining moisture content is also reduces the price of products. A great lack of an adequate insurance or relief from government against natural calamities in proportion to area cultivated and crop conditions.

Table.1 Area, production and productivity of cumin in Rajasthan during 2012-13

\begin{tabular}{|l|l|l|l|}
\hline Districts & Area(ha) & Production (t) & Productivity (kg/ha) \\
\hline Barmer & 137370 & 33635 & 245 \\
\hline Jalore & 122620 & 41932 & 342 \\
\hline Jodhpur & 106058 & 44663 & 421 \\
\hline Nagaur & 46590 & 25108 & 539 \\
\hline Jaisalmer & 29740 & 6589 & 222 \\
\hline Pali & 15341 & 6425 & 419 \\
\hline Sirohi & 15341 & 2204 & 473 \\
\hline Others districts & 22631 & 15802 & \\
\hline $\begin{array}{l}\text { \% contribution in state } \\
\text { production }\end{array}$ & $95 \%$ & $91 \%$ & \\
\hline Rajasthan & 495691 & 118352 & 356 \\
\hline Gujarat & 370600 & 259500 & 700 \\
\hline
\end{tabular}

Source: Vital Agriculture Statistics (2012-13): Directorate of Agriculture, Rajasthan, Jaipur

Table.2 Comparison of Improved v/s farmers practices for cumin cultivation

\begin{tabular}{|c|c|c|c|}
\hline $\begin{array}{l}\text { S. } \\
\text { No. }\end{array}$ & Particular & Improved package Practice & Farmers practices \\
\hline 1. & Variety & GC 4, RZ 223 & Local \\
\hline 2. & Seed rate & $05 \mathrm{~kg} / \mathrm{ha}$ & $15-20 \mathrm{~kg} / \mathrm{ha}$ \\
\hline 3. & Seed treatment & $\begin{array}{l}\text { - Carbendazim @ 3g/kg. } \\
\text { - PSB + Azotobactor } 500 \mathrm{~g} / \mathrm{ha} \text { each } \\
\text { - application of Trichoderma @ } 2.5 \\
\text { kg/ha }\end{array}$ & Not applied \\
\hline 4. & Sowing method & Line Sowing & Broadcasting \\
\hline 5. & Fertilizer doses & 30: 22: $00(\mathrm{~N}: \mathrm{P}: \mathrm{K} \mathrm{kg} / \mathrm{ha})$ & Imbalance use \\
\hline 6. & $\begin{array}{l}\text { Plant protection } \\
\text { measures }\end{array}$ & Need based spray of pesticides & No use of pesticides \\
\hline
\end{tabular}


Table.3 Production constraints in cumin production

\begin{tabular}{|l|l|l|l|l|}
\hline \multirow{2}{*}{ Practices/ villages } & \multicolumn{3}{l|}{ Farmers' response (\%) } & \multirow{2}{*}{ Rank } \\
\cline { 2 - 5 } & Dudasar & Mittiberi & Laxmanpura & \\
\hline Improved seed (Govt. verified ) & 54 & 60 & 53 & II \\
\hline Awareness about seed treatment & 46 & 44 & 65 & III \\
\hline Seed resistant to wilt \& blight & 31 & 32 & 41 & VI \\
\hline High cost of fertilizers & 38 & 36 & 41 & V \\
\hline Timely availability of fertilzers (FOR) & 27 & 24 & 29 & VII \\
\hline Lack of control measures for wilt & 38 & 36 & 41 & V \\
\hline Non availability of timely labour & 23 & 16 & 24 & VIII \\
\hline Lack of seed drill for sowing & 62 & 56 & 76 & I \\
\hline Availability of electricity for irrigation & 42 & 44 & 47 & IV \\
\hline Poor texture of soil & 12 & 16 & 24 & IX \\
\hline Poor economic condition & 12 & 12 & 18 & X \\
\hline
\end{tabular}

Table.4 Marketing constraints in cumin production

\begin{tabular}{|l|l|l|l|l|}
\hline \multirow{2}{*}{ Practices/ villages } & \multicolumn{3}{|c|}{ Farmers response (\%) } & Rank \\
\cline { 2 - 5 } & Dudasar & Mittiberi & Laxmanpura & \\
\hline $\begin{array}{l}\text { Declaration of Minimum support } \\
\text { prices }\end{array}$ & 77 & 68 & 53 & II \\
\hline Processing units & 62 & 56 & 59 & IV \\
\hline Loaning facility & 73 & 60 & 82 & I \\
\hline Adequate crop insurance & 58 & 40 & 65 & V \\
\hline Storage structures & 69 & 60 & 53 & III \\
\hline Transportation & 38 & 36 & 41 & VII \\
\hline Lack of moisture estimations & 38 & 44 & 47 & VI \\
\hline
\end{tabular}

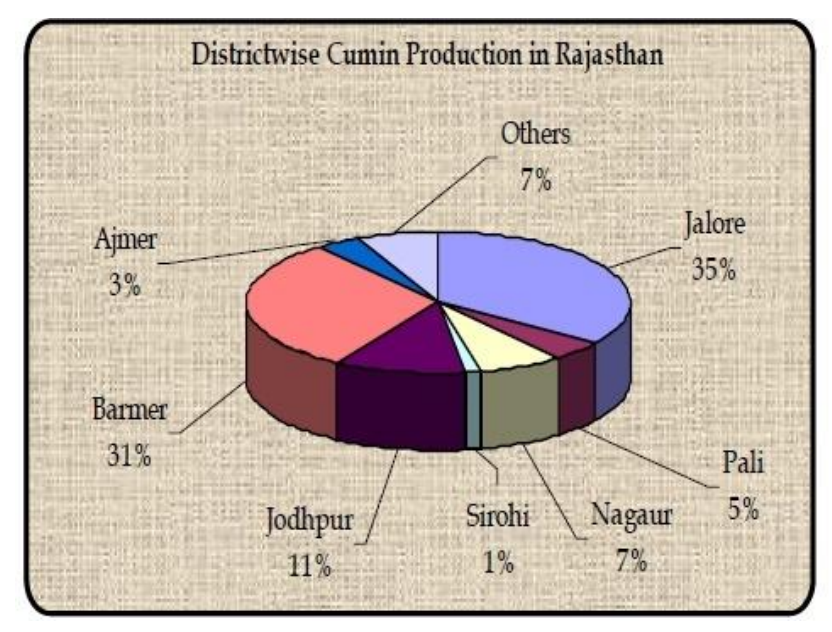




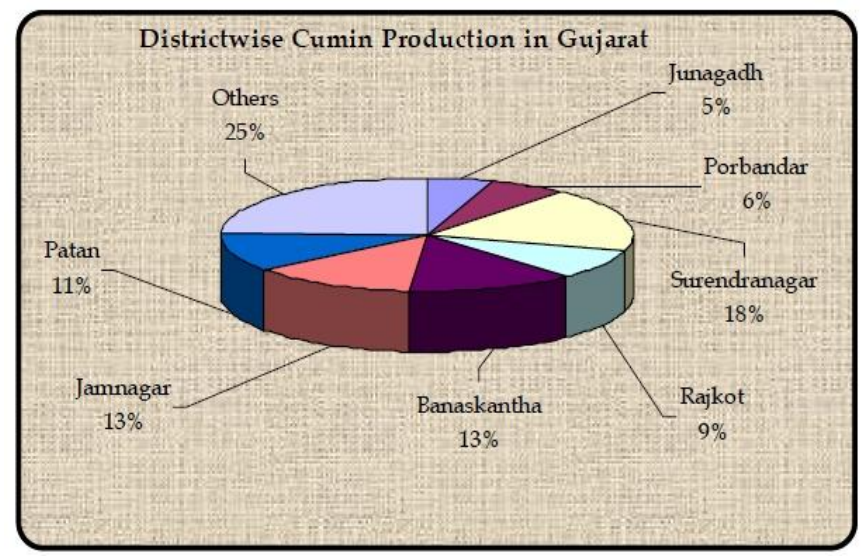

To understand the behaviour of farmers towards selling of their produce in another state, it was concluded that the broker of Unjha and Deesa mandi purchase the produce without processing like sieving and grading, fix the prizes in standing crops, loaning against produce if farmer do not sold their produce so farmers sold their produce as early as threshed because moisture content also pays the return.

From above study it may be concluded that adoption of improved technologies is easy but constrains for its adoption as a hurdle race where one constrain solved gave birth to another constraints. As it is clear that the time of sowing never wait and it is top most non monetary input in crop production. So to sow the crop on time sacrificed by farmers either by using uncertified or untreated seed. The use of these practices makes the crop more vulnerable to increased incidence of wilt and blight. These practices also increased the cost of production in one hand and make it unfit of environment as well as export. Similar finding were reported by Jain and Pagaria (2011), Jain (2014) and Singh et al, 2011. Thus, overall market and government policies may make the Rajasthan as most productive state.
It is suggested that there is a need to strengthen effective communication methods like SMS services, leaflets, technical bulletins, newspapers, radio talk, trainings etc. to timely availability of inputs and management of weather aberrations.

\section{References}

Choudhary, M.L. and Pagaria P. (2012). Demonstration-An effective technology for increasing the productivity of cumin. Agric. Update, 7 (1\&2): 99-101.

Jain L.K. 2014. Economics and gap analysis in isabgol cultivation through frontline demonstrations in western Rajasthan. Int. J. Agr. Ext. 02(02) 2014. 109-114.

Jain, L.K. and Pagaria, P., (2011). Adoption behavior of cumin cultivation towards improved technology. Indian J. of Agricultural Research and Extension 4:85-88.

Veerasamy, S., Satpathy, C. and Rao, G.A. (2003). Constraints of coriander production in Orissa. Indian Res. $J$. Extn. Edu. 33(1\&2):58-63.

Vital Agriculture Statistics (2012-13). Directorate of Agriculture, Govt. of Rajasthan.

\section{How to cite this article:}

Pradeep Pagaria and Sonali Sharma. 2019. Production and Marketing Constraints for Cumin Seed in Barmer District. Int.J.Curr.Microbiol.App.Sci. 8(03): 1828-1832.

doi: https://doi.org/10.20546/ijcmas.2019.803.216 